\title{
Characterization of turtle demineralized bone matrix (DBM) and turtle bone in rat radial bone defects; radiological, histopathological, biomechanical and scanning electron microscopic evaluation
}

\author{
Ahmad Oryan ${ }^{1}$, Amin Bigham-Sadegh ${ }^{2 *}$, and Somayeh Monazzah ${ }^{3}$ \\ 'Department of Pathology, School of Veterinary Medicine, Shiraz University, Shiraz, Iran \\ ${ }^{2}$ Department of Veterinary Surgery and Radiology, Faculty of Veterinary Medicine, Shahr-e-Kord University, \\ Shahr-e-Kord, Iran \\ ${ }^{3}$ Department of Pathology, School of Veterinary Medicine, Shiraz University, Shiraz, Iran
}

ORYAN, A., A. BIGHAM-SADEGH, S. MONAZZAH: Characterization of turtle demineralized bone matrix (DBM) and turtle bone in rat radial bone defects; radiological, histopathological, biomechanical and scanning electron microscopic evaluation. Vet. arhiv 87, 523-534, 2017.

\section{ABSTRACT}

Bone grafts are used to treat various disorders, including delayed union and nonunion of fractures, congenital pseudoarthrosis, and osseous defects from trauma, infection, and tumors. The disadvantages of allografts, such as disease transmission, have led to the exploration of xenografts as an alternative grafting material. We used turtle DBM and turtle bone grafts in this study. A critical size defect of 2.5 times diameter elongation was created in the radial diaphysis of 16 rats in this study. The rats were divided into 4 groups: defect as control-, autograft as control+, turtle bone and turtle DBM. The results of radiological, histopathological, biomechanical and scanning electron microscopic evaluation of groups were compared. The biomechanical and radiological evaluation shows that there was no significant difference between groups; but histopathological evaluation shows significant differences between groups in union and cancellous bone. The turtle DBM group had the same result as control+ and was superior to the other groups.

Key words: fracture healing, xenograft, turtle bone, turtle demineralized bone matrix, Rat model

\section{Introduction}

Approximately ten percent of bone fractures experience delay in healing, even with use of treatment methods (ORYAN et al., 2014a). Fracture healing is an important process that depends on specialized cell functions and cell proliferation during the period of

\footnotetext{
*Corresponding author:

Amin Bigham-Sadegh, DVM, DVSc, Department of Veterinary Surgery and Radiology, School of Veterinary Medicine, Shahrekord University, Postal code: 8818634141, PO Box: 115, Shahrekord, Iran, E-mail: dr.bigham@gmail.com
} 
injury repair (SON et al., 2012; BIGHAM-SADEGH and ORYAN, 2015). Bone is a tissue that continuously undergoes resorption, deposition of stromal matrix, and remodeling (BIGHAM-SADEGH and ORYAN, 2015). These processes may be altered by cellular and pathological mechanisms (PILITSIS et al., 2002). Researchers are developing new technologies to improve fracture healing (EINHORN, 1998). Bone grafts are usually used to treat disorders such as delayed union and nonunion of fractures, and bone defects from trauma, infection, and tumors (HUNG, 2009). Bone substitutes are a complex and demanding undertaking (ORYAN et al., 2015). The problematic condition of allografts, including disease transmission, has led to the exploration of xenografts as an alternative grafting material (SHAFIEI SARVESTANI et al., 2011). DBM is osteoconductive when implanted in a bone defect (PRECHEUR, 2007). The bone of animals such as turtles and tortoises has not been used so far in orthopedic surgery. Turtle shell is a multi-scale biocomposite in which the components are arranged in various spatial patterns, creating a strong and durable structure (HERBST et al., 1999). In studies, the turtle is often considered to be an emblem of strength, longevity, and endurance and has been used in medicinal cuisine and as an energizer in tonics in China, Japan, and Korea since ancient times (GOSSLING et al., 2004). Xenografts are a type of bone graft that is harvested from animals' bodies and used to reconstruct the defect area (MEIMANDI et al., 2015). They are more popular than autografts and allografts, because they have low cost and are more readily available (ORYAN et al., 2014a). There are numerous studies which have compared the effect of xenografts in healing, such as bovine grafts and Coralline, with the available autograft (BIGHAM-SADEGH and ORYAN, 2015). DBM is one of the few xenografts that exhibits osteoconductive and osteoinductive properties (YIN et al., 2005). If it used with internal fixation devices it may have good results in the healing process (MEIMANDIPARIZI et al., 2012). DBM may be produced form allogenic or xenogenic sources such as bovine bone (KARIMI et al., 2013). There are also a few studies about DBM obtained from other animals. DBM is composed of collagen and noncollagenous, and growth factors (HIRASAWA et al., 2002). The decalcification process exposes bone proteins and growth factors for enhancing the bone healing process (KHOSHZABAN et al., 2011). The purpose of this study was evaluation of turtle DBM and turtle bone graft effects on bone healing in a rat model.

\section{Materials and methods}

Animals. Animal models are commonly used in the study of skeletal biology. Rats are the animals most often used in experiments studying the response of the musculoskeletal system to exercise, because they are simple, relatively inexpensive, and have good animal compliance (MARTINIAKOVA et al., 2009). Animal selection and management, surgical protocol, and preparations followed procedures approved by the Institutional Animal Care and Use Committee authorized by the ethics committee of the University. 
Sixteen adolescent, , white Sprague-Dawley, female rats, weighing $200 \mathrm{~g}$ were used. They were maintained in plastic cages in a room with a $12 \mathrm{~h}$-day/night cycle and an ambient temperature of $24^{\circ} \mathrm{C}$, and were allowed ad libitum access to water and standard laboratory pellets (BK001P, B\&K Universal Ltd., Grimstone Aldbrough, Hull, UK), consisting of 18 $\%$. They were randomized into four equal groups in 8 plastic cages.

Preparation of the turtle demineralized bone matrix. DBM was prepared from turtle bone collected from the aquatic department of Shiraz veterinary school. The bones were collected aseptically, and the soft tissues were removed. The bones were later cut into $1 \times 1 \mathrm{~cm}$ pieces with a wire cutter. The pieces were then thawed in ethanol and air dried. All the bones were milled and placed through a sieve to collect $1 \times 1 \times 1 \mathrm{~mm}^{3}$ pieces. The pieces were then decalcified in $0.6 \mathrm{~mol} / \mathrm{L}$ formic acid. Demineralization was evaluated by radiography. Some bone pieces were stored without demineralization.

Surgical technique. The animals were anaesthetized with ketamine $(40 \mathrm{mg} / \mathrm{kg}$, IM) and xylazine (5 mg/kg, IM). The left and right forelimb were shaved and prepared aseptically with povidon iodine, and the limb was draped with sterile drapes. An incision was made directly over the radius, which was then exposed by moving the surrounding muscles aside. An osteoperiosteal segmental defect was then created on the middle portion of each radius, at least twice as long as the diameter of the diaphysis, for creation of a non-union model (BIGHAM-SADEGH and ORYAN, 2015).

The defected area was filled with the removed bone in the same animal in the autograft group in 4 rats as a positive control; in 4 rats it was filled with prepared turtle bone; in 4 other rats it was filled with prepared turtle DBM, finally in 4 rats the defect was left empty, as the negative control group. The muscles and skin were sutured routinely to cover the defect area.

Biomechanical evaluation. A biomechanical test was conducted on the injured radial bones of each rat. The three-point bending test was performed postoperatively after 56 days to evaluate the biomechanical properties of the defect. The behavior of each sample under loading was characterized by determining the Strain, Stress, Stiffness and maximum load from the load deformation to the destruction curve. For this purpose, the bone ends were placed between the two jaws in the testing machine and the load was exerted at the injured healing area (a rate of $3 \mathrm{~mm} / \mathrm{sec}$ ) until failure, and the force needed to break the bones is recorded. Data derived from mechanical testing were expressed as the mean ( \pm SEM) for each group. Biomechanical properties were calculated with following formula:

Strain: calculated by dividing the extension by the original length of the specimen.

Stress: maximum load in proportion to cross sectional area

Maximum Load: maximum point on the Force-displacement curve

Stiffness: easily calculated by measuring the slope of a line drawn as a tangent to the curve at any defined point 
Radiological evaluation. To evaluate bone formation, proximal and distal union, and remodeling of the defect, lateral radiographs of each forelimb were taken postoperatively on the $1^{\text {st }}, 35^{\text {th }}$ and $56^{\text {th }}$ days to evaluate bone formation, union, and remodeling of the defect. The results were scored using a modified Lane and Sandhu scoring system (LANE and SANDHU, 1987). The bone formation between the bone grafts and the end of the proximal segment of the radius bone was considered as the proximal union, and the bone formation between bone grafts and the end of the distal segment of the radius bone was considered as the distal union. Remodeling of the healed bone was surveyed carefully.

Histopathological evaluation. In histopathological evaluation, union, cancellous bone, cortical bone and bone marrow formation were analyzed and scored (ORYAN et al., 2010; HEIPLE et al., 1987). Histopathological evaluation was carried out on 4 rats from each group. Both forelimbs were harvested and dissected free of soft tissues. Sagittal sections containing the defect site were cut with a slow speed saw. Each slice was then fixed in $10 \%$ formalin. The formalin-fixed bone samples were decalcified in $15 \%$ buffered formic acid solution and processed for routine histological examination. Thirty-two thin sections were cut from the centers of each specimen and stained with Hematoxylin and Eosin; the scoring system was according to the Lane and Sandhu modified scoring system used by HEIPLE et al., 1987.

Scanning electron microscopy. Scanning electron microscopy (SEM) provides much higher magnifications and better depth of field than optical microscopes. Therefore, SEM plays an important role in morphological examination of hard tissues. The samples were cut in to $1 \times 1 \mathrm{~cm}$ pieces. Then this protocol was used for preparation of samples:

- Fix tissue with Karnovsky solution containing 2.5\% glutaraldehyde and $2 \%$ paraformaldehyde in $0.1 \mathrm{M}$ phosphate buffer $(\mathrm{pH} 7.2-7.4)$ for $24-48$ hours at $4{ }^{\circ} \mathrm{C}$.

- Rinse tissue with distilled water

- Immerse in a $\mathrm{NaOH}$ solution for 3-5 days at room temperature to remove the adherent tissues.

- Rinse with distilled water for $12 \mathrm{~h}$ at $4{ }^{\circ} \mathrm{C}$

- Post-fix tissue in $1 \%$ osmium tetroxide for $2 \mathrm{~h}$ at $4{ }^{\circ} \mathrm{C}$.

- Dehydrate tissue with ascending graded ethanol $(70 \%, 80 \%, 90 \%, 95 \%, 100 \%$ ethanol)

- Dry with $\mathrm{CO} 2$ liquid in a critical point dryer or in air

- Mount on metal stubs

- Coat with gold/palladium using an ion sputter.

Statistical analysis. The radiological and histopathology data were compared using Kruskal-Wallis, non- parametric ANOVA, when P-values were found to be less than 0.05 , then pair wise group comparisons were performed by the Mann-Whitney $U$ test. Biomechanical data were compared with one way ANOVA, when P-values were less than 0.05 they were considered statistically significant (SPSS version 16 for Windows). 


\section{Results}

Gross evaluation. Rats were controlled for lameness and how they moved every day. The risk of infection in the surgical wound site was assessed daily. None of the animals were able to move 3 days after operation and could not use their claws for two weeks after the operation (they could not take hold of the bars of the cage). Fifty-six days after surgery, the rats were euthanized using intra-peritoneum magnesium sulfate. After cutting and separating the left and right claws of the rats and removing the soft tissues (skin, fascia and muscles), the radius bone and the healing of the experimental defect were evaluated grossly.

Biomechanical evaluation. Biomechanical parameters (Strain, Stiffness, Stress, and Maximum Load) were analyzed with SPSS software and the Kruskal-Wallis test was performed for each group, comparing them with the control- and control+ groups. There is no significant difference between the groups in terms of biomechanical parameters (Table 1).

Table 1. Comparison of the biomechanical parameters of the injured bones treated, using turtle bone and turtle DBM with autograft and untreated control (Mean $\pm \mathrm{SD})$

\begin{tabular}{|l|c|c|c|c|c|}
\hline Parameter & Control- & Control+ & Turtle bone & Turtle DBM & P-value \\
\hline Strain $(\%)$ & $0.79 \pm 0.5$ & $0.80 \pm 0.3$ & $0.43 \pm 0.1$ & $0.80 \pm 0.3$ & 0.580 \\
\hline Stiffness $(\mathrm{N} / \mathrm{mm})$ & $19.00 \pm 4.3$ & $20.33 \pm 9.0$ & $18.33 \pm 3.7$ & $13.33 \pm 4.4$ & 0.267 \\
\hline Stress $(\mathrm{N} / \mathrm{mm} 2)$ & $4.24 \pm 1.4$ & $4.71 \pm 1.4$ & $4.24 \pm 0.7$ & $5.66 \pm 1.8$ & 0.655 \\
\hline Maximum Load (N) & $30.00 \pm 10.0$ & $33.33 \pm 10.4$ & $30.00 \pm 5.0$ & $40.00 \pm 13.2$ & 0.655 \\
\hline
\end{tabular}

Radiological evaluation. Radiological parameters (Bone Formation, Proximal Union, Distal Union, and Remodeling) were analyzed with SPSS software, and the KruskalWallis test was performed for each group, comparing it with the control- and control+ groups. There was no significant difference between groups in terms of radiological parameters at 35 days post operation, nor at 56 days post operation (Table 2, Fig 1).

Table 2. Comparison of the Radiologic evaluation of the injured bones treated, using turtle bone and turtle DBM with autograft and untreated control Kruskal-Wallis test

\begin{tabular}{|l|l|c|c|c|c|c|}
\hline \multirow{4}{*}{$\begin{array}{l}35^{\text {th }} \text { days } \\
\text { after } \\
\text { operation }\end{array}$} & Parameter & Control- & Control+ & Turtle bone & Turtel DBM & P-value \\
\cline { 2 - 7 } & Bone formation & $1(1-1)$ & $3(1-2)$ & $0(0-1)$ & $1(0-2)$ & 0.153 \\
\cline { 2 - 7 } & Proximal union & $1(0-2)$ & $0(0-1)$ & $0(0-1)$ & $0(0-1)$ & 0.997 \\
\cline { 2 - 7 } & Distal union & $0(0-0)$ & $2(0-2)$ & $0(0-0)$ & $1(0-1)$ & 0.202 \\
\cline { 2 - 7 } & Remodeling & $1(0-1)$ & $0(0-0)$ & $0(0-0)$ & $0(0-0)$ & 0.392 \\
\hline \multirow{3}{*}{$\begin{array}{l}56^{\text {th }} \text { days } \\
\text { after } \\
\text { operation }\end{array}$} & Bone formation & $0(2-2)$ & $3(1-4)$ & $0(0-1)$ & $1(0-2)$ & 0.353 \\
\cline { 2 - 7 } & Proximal union & $1(0-2)$ & $2(1-2)$ & $1(0-1)$ & $0(0-1)$ & 0.574 \\
\cline { 2 - 7 } & Distal union & $0(1-1)$ & $2(0-2)$ & $0(0-0)$ & $1(0-1)$ & 0.741 \\
\cline { 2 - 7 } & Remodeling & $0(0-0)$ & $3(0-2)$ & $1(0-0)$ & $1(0-0)$ & 0.104 \\
\hline
\end{tabular}



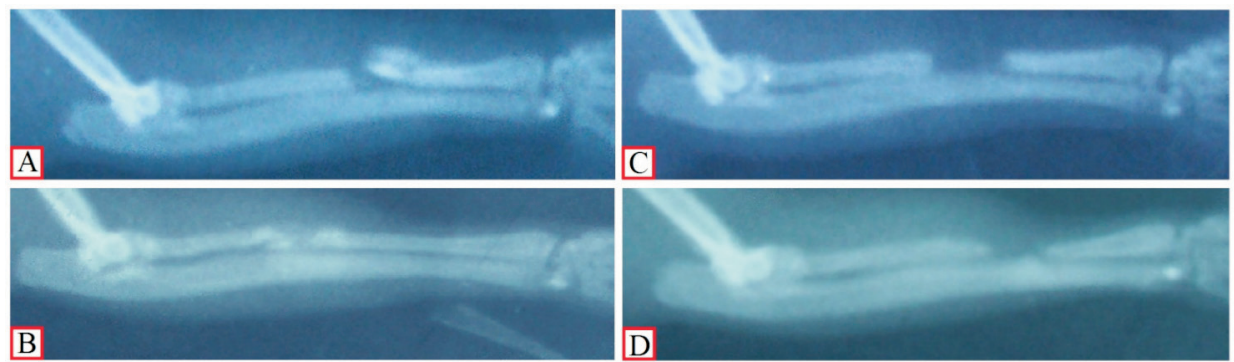

Fig. 1. A turtle bone graft 35 days post operation; B turtle bone graft 56 days post operation, $\mathrm{C}$ turtle DBM 35 days post operation, D turtle DBM 56 days post operation.

Histopathological evaluation. Histopathological parameters (Union, cancellous bone, cortical bone, Bone marrow) were analyzed with SPSS software, and the KruskalWallis test was performed for each group comparing it with the control- and control+ groups. In the histological evaluation there was no significant difference between the groups in terms of cortical bone and bone marrow; but there was a significant difference between the groups in union and cancellous bone, where the turtle DBM and autograft groups were superior to the other groups in union criteria, and the turtle DBM group was superior to the other groups in cancellous bone formation criteria. Also the control- group was inferior to the other groups (Table 3, Figs 2 and 3).

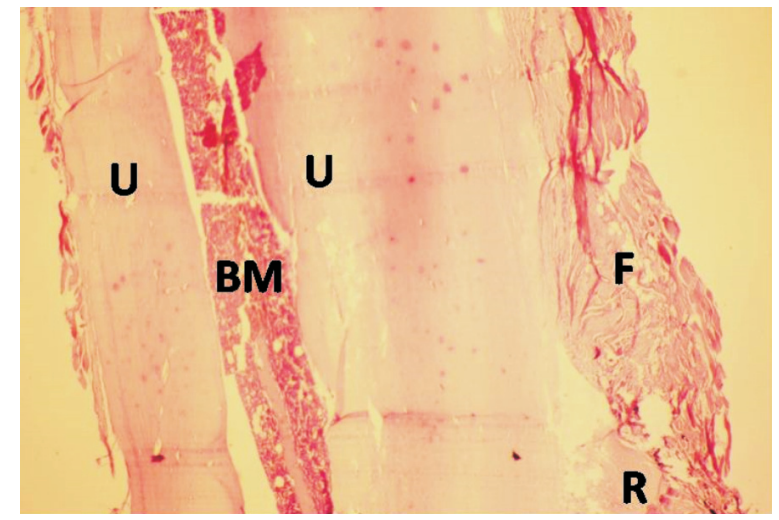

Fig. 2. Turtle bone graft: The defect has been filled with fibrous tissue. Radius (R), bone marrow $(\mathrm{BM})$, ulna (U), fibrous tissue (F) 


\section{A. Oryan et al.: Effects of turtle DBM and turtle bone on bone healing}

Table 3. Comparison of the Histopathological evaluation of the injured bones treated, using turtle bone and turtle DBM with autograft and untreated

\begin{tabular}{|l|c|c|c|c|c|}
\hline & Control- & Control+ & Turtle Bone & Turtle DBM & P-value \\
\hline Union & $0(0-0)$ & $2(1-3)$ & $0(1-1)$ & $2(1-3)^{\mathrm{a}}$ & $0.007^{*}$ \\
\hline Cancellous bone & $0(0-0)$ & $0(0-1)$ & $0(0-0)$ & $3(1-2)^{\mathrm{b}}$ & $0.002^{*}$ \\
\hline Cortical bone & $0(0-0)$ & $0(0-0)$ & $0(0-0)$ & $0(0-0)$ & 1.000 \\
\hline Bone marrow & $0(0-0)$ & $0(0-0)$ & $0(0-0)$ & $0(0-0)$ & 1.000 \\
\hline
\end{tabular}

*There is significant difference between groups in Kruskal-Wallis test. ${ }^{\mathrm{a}, \mathrm{b}}$ Turtle DBM was superior than other groups

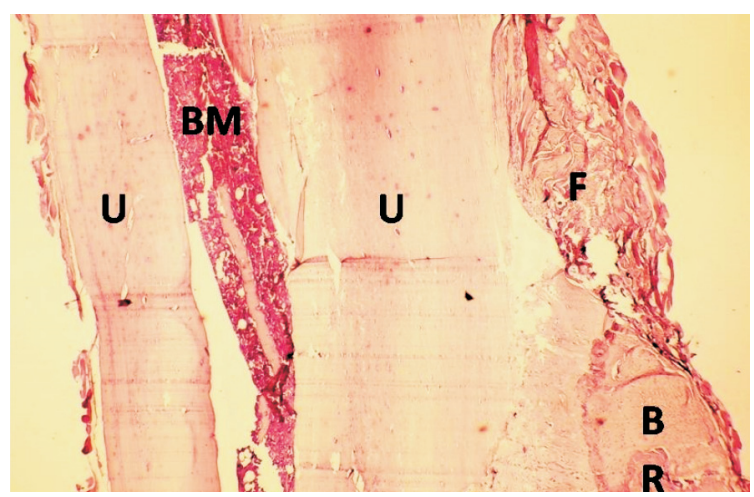

Fig. 3. Turtle DBM graft: The defect has been filled with fibrous tissue. Some new bone formation is seen in the end of the radius bone: Ulna (U), bone marrow (BM), radius (R), fibrous (F), Bone formation (B).

Scanning electron microscopy. Scanning electron microscopy (SEM) gives a threedimensional view of structures, with greater resolution and a better view at both microand nanoscale levels. Scanning by electron microscopy examination of the cross-sections of the defect site of radius showed that, in some cases, the microstructure was not homogeneous throughout the section. SEM of mineralized bone showed rough surfaces with small pits representing empty lacunae. There was trabecular bone with smooth surfaced trabecula. The flattened surface contained pores. Different grafted bones had similar micro architecture: a dense collagen fiber meshwork with osteocytic lacunae. In some cases the new bone formation did not fill the defect perfectly. The porosity of different samples differed. Also the amount of mineralization differed between cases. The margin of the new bone formation was distinct. The new bone formation fused the autograft bone and the end of the host bone (Figs 4 and 5). 
A. Oryan et al.: Effects of turtle DBM and turtle bone on bone healing

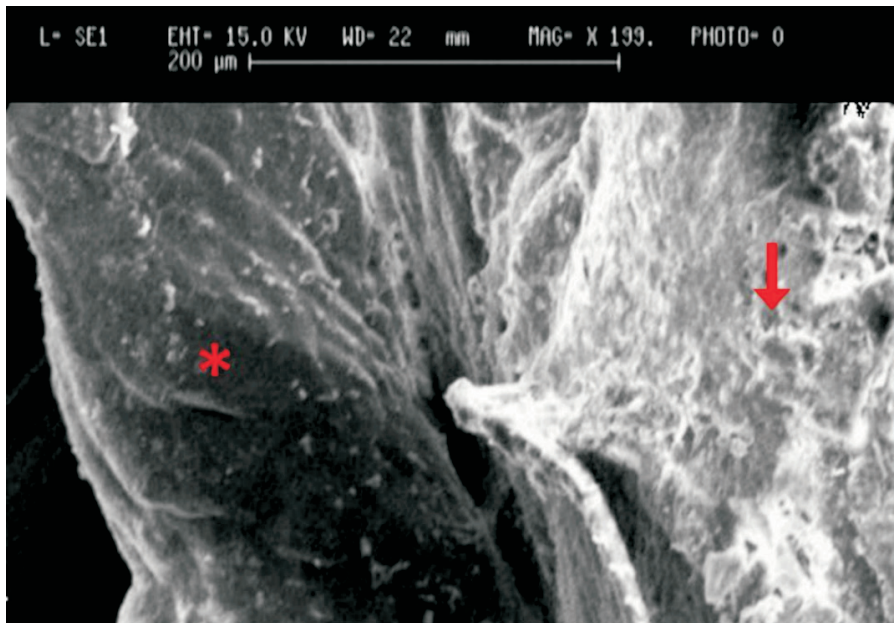

Fig. 4. SEM shows granulation tissue $\left(_{*}\right)$ in defect site and ulna $(\rightarrow)$ turtle bone graft

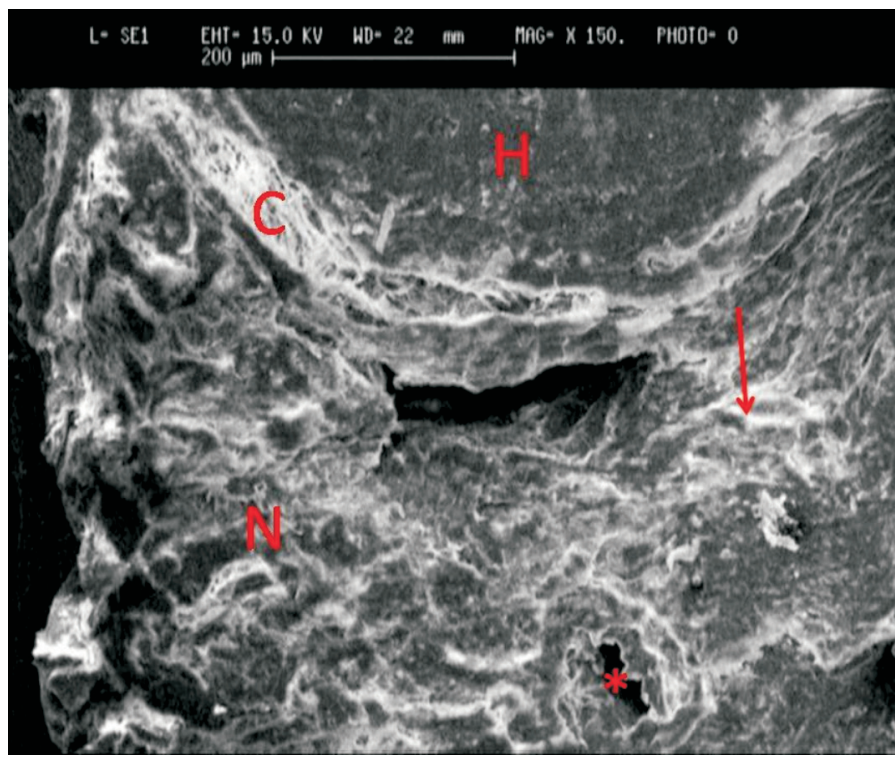

Fig. 5. SEM shows new bone formation $(\mathrm{N})$ in defect site, host bone $(\mathrm{H})$ collagen fibrils $(\mathrm{C})$, some capillaries $(*)$ and mineralized matrix (arrow) are seen in new bone formed (turtle DBM graft) 


\section{A. Oryan et al.: Effects of turtle DBM and turtle bone on bone healing}

\section{Discussion}

To evaluate the bone healing potential of turtle bone and turtle DBM, a defect model was established in the radial bone of rats. This model has previously been reported suitable because there is no need for internal or external fixation, which influences the healing process (BIGHAM-SADEGH and ORYAN, 2015). The segmental defect was created in the middle portion of the radius as long as 2.5 times the radius diameter to induce a nonunion defect and to prevent spontaneous and rapid healing. The rat model was used to study bone healing because of its low cost and the similarity of bone healing.

In the present study, we used turtle DBM and a turtle bone graft as a source of osteoinductive material. In a different study the materials tested included different mineralized and demineralized animal bones (DOHERTY et al., 1994). Autogenous bone is the gold standard for bone graft material in orthopedic surgery (MOSHIRI et al., 2015) and we used that as control+ in our study to compare it with turtle DBM and the turtle bone graft; the empty or untreated defect was designated the control-. We decalcified turtle bone to expose osteoinductive growth factors from the mineralized matrix, thereby enhancing the bone formation process. There is higher variability in concentration of BMPs among the same DBM (ORYAN et al., 2014b). This variability questions DBM product reliability and, possibly, their efficacy in providing consistent osteoinduction (BIGHAM-SADEGH et al., 2013). The demineralization process also destroys the antigenic materials in bone, making DBM less immunogenic than a mineralized allograft (BIGHAM-SADEGH et al., 2015). In scanning electron microscopy a low amount of mineralization was observable that was confirmed by the radiological findings, as seen in the radiographs. The results of animal studies indicate variations in performance within and among DBM products. The majority of human clinical trials report high fusion rates when DBM is employed as a graft extender or a graft (MEIMANDI et al., 2015). A few prospective randomized controlled trials have been performed comparing DBM to autologous iliac crest bone graft in spine fusion (ORYAN et al., 2015). DBM is able to function as a graft extender in humans (LIEBSCHNER, 2004). After demineralization, DBM retains much of the proteinaceous components native to bone, with small amounts of calcium-based solids, inorganic phosphates and some trace cell debris (ORYAN et al., 2014b). Previous experimental studies have demonstrated that the implantation of DBM into subcutaneous or muscular sites induces the proliferation of mesenchymal stem cells which differentiate to cartilage cells (MOSHIRI and ORYAN, 2013) and the synthesis of cartilage tissues, and subsequently there is a process similar to endochondral ossification. This happens because of the osteoinductivity of DBM (WANG et al., 2000). The osteoinductivity of DBM is related to the release of BMP in the implanted sites (BIGHAM et al., 2008). DBM supports new bone formation through osteoconductive mechanisms (MOSHIRI et al., 2015). The primary osteoinductive components of DBM are bone morphogenetic proteins (BMPs). Biomechanical and radiological evaluation showed that there was no significant 


\section{A. Oryan et al.: Effects of turtle DBM and turtle bone on bone healing}

difference between the groups; but histopathological evaluation showed a significant difference between the groups in terms of union and cancellous bone. Turtle DBM had an analogous result compared to control+ and they were both superior to the other groups. In histopathological evaluation turtle DBM was superior to the other groups in terms of cancellous bone. It showed that turtle DBM is more effective in healing radial bone defects in a rat model.

\section{Acknowledgements}

The authors would like to thank the authorities of the Shiraz University for their financial support and cooperation.

\section{Conflict of interest: None}

Ethical statement: All applicable international, national, and/or institutional guidelines for the care and use of animals were followed.

\section{Reference}

BIGHAM-SADEGH, A., I. KARIMI, M. ALEBOUYE, Z. SHAFIE-SARVESTANI, A. ORYAN (2013): Evaluation of bone healing in canine tibial defects filled with cortical autograft, commercial-DBM, calf fetal DBM, omentum and omentum-calf fetal DBM. J. Vet. Sci. 14, 337-343.

BIGHAM-SADEGH, A., I. KARIMI, S.-E. SHARIATI, A. ORYAN (2015): The role of cortical autograft, commercial-demineralized bone matrix, calf fetal demineralized bone matrix and calf fetal growth plate powder on bone healing in rabbits. Vet. arhiv 85, 23-36.

BIGHAM-SADEGH, A., A. ORYAN (2015): Selection of animal models for pre-clinical strategies in evaluating the fracture healing, bone graft substitutes and bone tissue regeneration and engineering. Connect. Tissue. Res. 56, 175-194.

BIGHAM, A. S., S. N. DEHGHANI, Z. SHAFIEI, S. T. NEZHAD (2008): Xenogenic demineralized bone matrix and fresh autogenous cortical bone effects on experimental bone healing: radiological, histopathological and biomechanical evaluation. J. Orthop. Traumatol. 9, 73-80.

DOHERTY, M. J., G. SCHLAG, N. SCHWARZ, R. A. B. MOLLAN, P. C. NOLAN, D. J. WILSON (1994): Biocompatibility of xenogeneic bone, commercially available coral, a bioceramic and tissue sealant for human osteoblasts. Biomaterials 15, 601-608.

EINHORN, T. A. (1998): The cell and molecular biology of fracture healing. Clin. Orthop. Relat. Res. 355, S7-S21.

GOSSLING, S., T. KUNKEL, K. SCHUMACHER, M. ZILGER (2004): Use of molluscs, fish, and other marine taxa by tourism in Zanzibar, Tanzania. Biodivers. Conserv. 13, 2623-2639.

HEIPLE, K. G., V. M. GOLDBERG, A. E. POWELL, G. D. BOS, J. M. ZIKA (1987): Biology of cancellous bone grafts. Orthop. Clin. North. Am. 18, 179-185.

HERBST, L. H., E. R. JACOBSON, P. A. KLEIN, G. H. BALAZS, R. MORETTI, T. BROWN, J. P. SUNDBERG (1999): Comparative pathology and pathogenesis of spontaneous and 
experimentally induced fibropapillomas of green turtles (Chelonia mydas). Vet. Pathol. Online 36, 551-564.

HIRASAWA, Y., S. TAKAI, W.-C. KIM, N. TAKENAKA, N. YOSHINO, Y. WATANABE (2002): Biomechanical monitoring of healing bone based on acoustic emission technology. Clin. Orthop. Relat. Res. 402, 236-244.

HUNG, N. N. (2009): Use of an intramedullary Kirschner wire for treatment of congenital pseudarthrosis of the tibia in children. J. Pediatr. Orthop. B. 18, 79-85.

KARIMI, I., A. BIGHAM-SADEGH, A. ORYAN (2013): Concurrent Use of Greater Omentum with Persian Gulf Coral on Bone Healing in Dog: a Radiological and Histopathological Study. Iran. J. Vet. Surg. 8, 35-42.

KHOSHZABAN, A., S. MEHRZAD, V. TAVAKOLI, S. H. KESHEL, G. R. BEHROUZI, M. BASHTAR (2011): The comparative effectiveness of demineralized bone matrix, betatricalcium phosphate, and bovine-derived anorganic bone matrix on inflammation and bone formation using a paired calvarial defect model in rats. Clin. Cosmet. Investig. Dent. 3, 69-78.

LANE, J. M., H. S. SANDHU (1987): Current approaches to experimental bone grafting. Orthop. Clin. North. Am. 18, 213-225.

LIEBSCHNER, M. A. K. (2004): Biomechanical considerations of animal models used in tissue engineering of bone. Biomaterials. 25, 1697-1714.

MARTINIAKOVA, M., R. OMELKA, B. GROSSKOPF, Z. MOKOSOVA, R. TOMAN (2009): Histological analysis of compact bone tissue in adult laboratory rats. Slovak. J. Anim. Sci. 42, 56-59.

MEIMANDI-PARIZI, A., A. ORYAN, Z. SHAFIEI-SARVESTANI, A. S. BIGHAM (2012): Human platelet rich plasma plus Persian Gulf coral effects on experimental bone healing in rabbit model: radiological, histological, macroscopical and biomechanical evaluation. J. Mater. Sci. Mater. Med. 23, 473-483.

MEIMANDI, A., A. ORYAN, S. HADDADI, A. B. SADEGH (2015): Bone healing properties of DBM and DBM-G90 in a rabbit model: histopathological and biomechanical evaluation. Acta. Orthop. Traumatol. Turc. 49, 683-689.

MOSHIRI, A., A. ORYAN (2013): Role of platelet rich plasma in soft and hard connective tissue healing: an evidence based review from basic to clinical application. Hard. Tissue. 2, 6.

MOSHIRI, A., M. SHAHREZAEE, B. SHEKARCHI, A. ORYAN, K. AZMA (2015): ThreeDimensional Porous Gelapin-Simvastatin Scaffolds Promoted Bone Defect Healing in Rabbits. Calcif. Tissue. Int. 96, 552-564.

ORYAN, A., S. ALIDADI, A. MOSHIRI, N. MAFFULLI (2014a): Bone regenerative medicine: classic options, novel strategies, and future directions. J. Orthop. Surg. Res. 9, 1-17.

ORYAN, A., S. MONAZZAH, A. BIGHAM-SADEGH (2015): Bone injury and fracture healing biology. Biomed. Environ. Sci. 28, 57-71.

ORYAN, A., A. MOSHIRI, A. MEIMANDI-PARIZI (2014b): Role of embedded pure xenogenous bovine platelet gel on experimental tendon healing, modelling and remodelling. BioDrugs. 28, 537-556. 
A. Oryan et al.: Effects of turtle DBM and turtle bone on bone healing

ORYAN, A., A. MOSHIRI, A.-H. MEIMANDIPARIZI (2010): Effects of sodium-hyaluronate and glucosamine-chondroitin sulfate on remodeling stage of tenotomized superficial digital flexor tendon in rabbits: a clinical, histopathological, ultrastructural, and biomechanical study. Connect. Tissue. Res. 52, 329-339.

PILITSIS, J. G., D. R. LUCAS, S. R. RENGACHARY (2002): Bone healing and spinal fusion. Neurosurg. Focus 13, 1-6.

PRECHEUR, H. V. (2007): Bone graft materials. Dent. Clin. North. Am. 51, 729-746.

SHAFIEI SARVESTANI, Z., A. MEIMANDI PARIZI, A. ORYAN, A. BIGHAM-SADEGH (2011): Effect of human platelet rich plasma on bone healing in rabbits. Online. J. Vet. Res. 3, 239-248.

SON, J., Y.-B. KIM, Z. GE, S.-H. CHOI, G. KIM (2012): Bone healing effects of diode laser (808 $\mathrm{nm}$ ) on a rat tibial fracture model. In Vivo 26, 703-709.

WANG, J., R. YANG, L. C. GERSTENFELD, M. J. GLIMCHER (2000): Characterization of demineralized bone matrix-induced osteogenesis in rat calvarial bone defects: III. Gene and protein expression. Calcif. Tissue. Int. 67, 314-320.

YIN, Y., J. HUANG, M. L. PAINE, V. N. REINHOLD, N. D. CHASTEEN (2005): Structural characterization of the major extrapallial fluid protein of the mollusc Mytilus edulis: implications for function. Biochem. 44, 10720-10731.

Received: 8 April 2016

Accepted: 28 February 2017

ORYAN, A., A. BIGHAM-SADEGH, S. MONAZZAH: Karakterizacija kornjačine demineralizirane koštane matrice i kornjačine kosti u svrhu cijeljenja defekata palčane kosti štakora: radiološka, patohistološka, biomehanička prosudba i prosudba skenirajućim elektronskim mikroskopom. Vet. arhiv 87, 523-534, 2017.

\section{SAŽETAK}

Koštani presadci rabe se za liječenje različitih poremećaja kao što je produženo vrijeme cijeljenja prijeloma, izostanak cijeljenja, kongenitalne pseudoartroze i drugi koštani poremećaji zbog traume, infekcije i tumora. Slabe strane alogeničnih presadaka poput primjerice prijenosa bolesti, dovele su do istraživanja upotrebe ksenogeničnih presadaka kao alternative. U radu je rabljena kornjačina demineralizirana koštana matrica i koštani presadci. Kritična veličina defekta od 2,5 puta dužine promjera učinjena je na dijafizi radijalne kosti (žbice) u 16 štakora. Štakori su bili podijeljeni u četiri skupine: negativnu kontrolnu skupinu s učinjenim defektom, pozitivnu kontrolnu skupinu s auto presatkom, skupinu kojoj je bila primijenjena kornjačina kost i skupinu kojoj je bila primijenjena kornjačina demineralizirana koštana matrica. Uspoređeni su rezultati radiološke, patohistološke, biomehaničke prosudbe i prosudbe skenirajućim elektronskim mikroskopom. Biomehanička i radiološka prosudba pokazala je da nije bilo značajne razlike među skupinama, dok je patohistološka prosudba pokazala značajnu razliku između skupina u cijeljenju i spongioznosti. Skupina kojoj je bila primijenjena kornjačina demineralizirana koštana matrica dala je iste rezultate kao pozitivna kontrolna skupina, što je rezultatski bilo iznad ostalih skupina.

Ključne riječi: cijeljenje prijeloma, ksenogenični presadak, kornjačina kost, kornjačina demineralizirana koštana matrica, štakor 